\title{
The Influence of Parent's Perception and Involvement in Purchasing Decision of Toys For Children
}

\author{
Milatul Ulfa* \\ Department of Family and Consumer Sciences, \\ Faculty of Human Ecology, \\ Bogor Agricultural University
}

\author{
Moh. Djemjem Djamaludin* \\ Department of Family and Consumer Sciences, \\ Faculty of Human Ecology, \\ Bogor Agricultural University
}

*Corresponding author: milfha.mu@gmail.com

\begin{abstract}
Toys are "the closest children's friend" and become an integral part of their play world. Toys are a source of joy for children, but they can be risky and dangerous. This study aimed to analyze the influence of family characteristics, perception, and parental involvement on purchasing decision of toys for children. This study used cross-sectional study design. The location was chosen purposively involving two pre-schools. The samples were 200 parents who had ever bought toys. The husband or wife as decision makers in purchasing toys was interviewed using a structured questionnaire to collect information in the decision to purchase toys. The results showed that the perception of toys had a positive and significant relationship with the involvement on purchasing decision of toys for children. Perception of toys also had influence on purchase frequence.
\end{abstract}

Key words: involvement, perception, purchasing decision, toys

\begin{abstract}
Abstrak. Produk mainan anak adalah "teman terdekat" anak dan menjadi bagian yang tidak terpisahkan dari anak-anak dalam bermain. Mainan anak merupakan sumber kegembiraan bagi anak, namun justru dipenuhi dengan resiko dan bahaya. Penelitian ini bertujuan untuk menganalisis pengaruh karakteristik keluarga, persepsi dan keterlibatan orangtua terhadap keputusan pembelian produk mainan anak. Desain penelitian ini menggunakan cross sectional study. Pemilihan lokasi penelitian dilakukan secara purposif dengan melibatkan dua Taman Kanak-kanak (TK). Melibatkan 200 orang tua yang pernah membeli produk mainan anak. Suami atau istri sebagai pengambil keputusan dalam pembelian produk mainan anak diwawancarai dengan menggunakan kuesioner terstruktur untuk menggali informasi keputusannya dalam pembelian produk mainan anak. Hasil penelitian menunjukkan bahwa persepsi mengenai produk mainan anak mempunyai hubungan positif dan signifikan dengan keterlibatan orang tua dalam memutuskan pembelian produk mainan anak. Terdapat pengaruh persepsi mengenai produk mainan anak terhadap frekuensi pembelian.
\end{abstract}

Kata kunci: keputusan pembelian produk maian anak, keterlibatan, persepsi, produk mainan anak 


\section{Introducation}

Indonesia is entering the era of free trade and higher competition. This era is driven by several factors including multilateral agreements, such as the ASEAN-China Free Trade Agreement (ACFTA) in 2010, the ASEAN Economic Community (AEC) in 2015, and the Asia Pacific Economic Cooperation (APEC) in 2020. This multilateral agreement is the challenge of global competition in which the goods, services, and labor entry Indonesia freely and compete with local products and labor. Yandri (2012) proved that ACFTA has impacted on Indonesia toy products. The market is dominated by China-made toys which are demanded 11.7 times higher than local toys. Indonesia is a potential market of toys because it has large population; in addition, the consumption patterns of Indonesian society are looking for bargains. Consequently, market local products are defeated gradually by products from China.

Based on the Regulation of the Decree of Minister of Industry of the Republic of Indonesia No. 24/M-IND/PER/4/2013, toy is any product or material designed or clearly intended for 14 year old children or under, which is obliged to meet the requirements of safety, security, or preservation of the environment. The toys are made from basic materials and substances that ensure the safety, security, and the preservation of the environment. However, the current free trade enables many toy products which are unsafe even some toys can cause an accident and poison the children.

The combination of the nation's current condition and the rapid development is demanding for immediate improvement. The family is the smallest unit of a society and plays an urgent role in giving the first and ultimate influences on individuals. Thus, family involvement is needed so that parents can monitor and protect children from toys. Kids choose a toy for the support of parents who provide various facilities. In this case, parents' perception play a role through their seeking information involvement in decision making of toys. Consumer involement comes from ego involvement based on a relationship with an object. Ego involvement occurs when an object has a personal and important meaning because it evokes a strong perception. Consumer involvement in purchasing decisions defines the perceived importance of a product or a personal relevance based on individuals' needs and values (Guthrie and Hye-Sin, 2009). Therefore, this study aimed to: (1) identify the characteristics of the family and the respondent (the length of education, age, family income, family size, child's gender, child's age, and child's order of birth); (2) identify priority selection before buying toys, perception, and parents' involvement in purchasing decision of toys; (3) analyze the relationship between perception and parents' involvement with purchasing decisions of toys; and (4) analyze the influence of the perception and the involvement of parents on purchasing decisions of toys.

\section{Method}

\section{Participants}

This study was designed by a cross sectional study and used the techniques of self-report data collection. This study was conducted in Cibinong Sub-District and Central Bogor Sub-District, West Java, which were selected purposively for each district was the capital city of Bogor Regency and Bogor City, respectively. Two 
kindergartens (TK) were selected purposively to represent the two sub-districts, namely TK Negeri Pembina in Bogor Regency and TK Negeri Mexindo in Bogor City. The respondents that were selected by using simple random sampling technique were parents of the students in those kindergartens and had ever bought toy products. Based on the Slovin formula, the number of samples was 200; 82 of TK Negeri Pembina Cibinong and 118 of TK Negeri Mexindo.

\section{Measures}

Data used in this study were primary data obtained through interview using a structured questionnaire. The variables covering in the questionnaire were the characteristics of the respondents (gender, age, length of education, occupation, family size, family income, birth order of the child, age of the child), perception, involvement, and purchasing decisions. Age of the respondents was divided into three categories (Papalia, Olds, and Feldman, 2008): young adult (age 20-40), middle age (age 41-65), and old age (age >65). Family size was divided into three categories (NPFPB, 2005): small ( $\leq 4$ people), medium (5-6 people), and big ( $\geq 7$ people). Birth order of child was divided into four categories: firstborn child, middle child, the youngest child, and only child. Age of child was categorized into four categories: 4 years, 5 years, 6 years, and 7 years.

Perception on toys was divided into three dimensions: perception based on the quality of the product, perception based on the emotional value, and perception based on the suitability of the price. This variable was measured using a modified statement items of Fauzi's questionnaire (2011), consists of 15 items with 4-point scale $(1=$ strongly disagree, $2=$ disagree, $3=$ agree, $4=$ strongly agree). The reliability score of this questionnaire was 0.879 and 15 valid items.

Involvement in purchasing decision of toys was divided into four dimensions: normative, subjective risk, long-term, and situational. This variable was measured by using modified questionnaire of Wijayanti (2009). There were 18 items rated on 4-point scale $(1=$ strongly disagree, $2=$ disagree, $3=$ agree, $4=$ strongly agree $)$ with the reliability score of 0.737 . Meanwhile, purchasing decision was measured by six questions covering the time, purpose, frequency within one year, amount of purchase in one time purchase, amount of expenses in one time purchase, and location. Perception, involvement and purchasing decisions were categorized into two: high (score $\leq 66.6$ ) and low (score $\geq 66.7$ ).

\section{Analysis}

Data analysis consisted of descriptive analysis and inferential analysis. Descriptive analysis included the maximum and minimum, average, and standard deviation. Inferential analysis included the correlation and regression tests, and the Ttest. Correlation test was used to analyze the relationship between each variable. Regression test was to analyze the effect of the characteristics of the respondents, respondents' perception and involvement in purchasing decision of toys. Meanwhile, Ttest was to analyze the difference between the male respondents and female respondents in terms of whether or not ever obtained information on the signs of SNI (Indonesian National Standard) on toy products. 


\section{Result}

\section{Respondent Characteristics}

The number of respondents in this study was 200 people. The proportion of female respondents $(69.5 \%)$ was more than male respondents $(30.5 \%)$. More than half of the respondents (76.0\%) were young adults (age 20-40), while the lowest proportion $(0.5 \%)$ was older adult (age >65). Formal education mostly taken by husbands $(53.5 \%)$ and wives $(47.5 \%)$ was higher education or more than 12 years. Almost all of the husbands $(44.0 \%)$ worked as private employees while the wives $(54.5 \%)$ did not work or as a housewife. The family size of respondents in both schools $(58.5 \%)$ was small family ( $\leq 4$ people). The family income ranged under Rp1.000.000 - more than Rp5.000.001. Nearly half of the respondents $(43.0 \%)$ had a family income per month ranged Rp2.500.001 - Rp5.000.000. More than half of the respondents' child was boys $(56.0 \%)$ and girls $(44.0 \%)$ and nearly half of them $(47.5 \%)$ were 5 years old. Meanwhile, less than half of the respondents were the eldest or the firstborn child of one or more siblings $(30.0 \%)$ and the only child $(35.5 \%)$.

\section{Priority Options in Purchase Decision of Toys}

Respondents considered various things before deciding to buy toys for their children. The main priority of the respondents was the location. The distance became the consideration in purchasing decision due to the time, costs, and the availability of the desired toys. The next priority was how to use the toys and the warning signs followed by the price. Respondents put the fifth priority to the material of toys. It indicates that the toys' material was not a primary consideration in purchasing decision of toys for the respondents' children. The toys' material in this study is heavy metals, such as Lead $(\mathrm{Pb})$, Mercury $(\mathrm{Hg})$, Chromium $(\mathrm{Cr})$, and Cadmium $(\mathrm{Cd})$. The chemicals contained in the toys could be found in plastics or rubber, paint with striking colors, or rechargeable battery materials that are certainly harmful for children's health.

The sixth priority was standard mark labeled SNI (Indonesian National Standard) or CE and others as proof that the toys had met the specified security requirements of authorized testing agencies. Almost all respondents $(80.5 \%)$ obtained information about SNI; thus, there were no significant differences between the male and female respondents $(p>0.05)$ in terms of whether or not getting information about SNI. The product label got the seventh priority, that is, respondents seldom read the label to check the appropriateness of the toys with the child's condition. However, the name tag contains many of the essential information concerning the security and safety of children, such as the age of the user manual, flame resistant, washable, non-toxic, and so forth. The eighth priority was the size of the toys. It is very important because it will also affect the safety of children.

Form of toys was the ninth priority in deciding the purchase of toys. Herjanto and Rahmi (2010) suggested the shapes of toys into three physical forms, namely soft toys (toys that contain soft materials), hard toys (toys made of hard materials such as wood, plastic, metal, etc.), and electrical toys (toys powered by electricity or batteries). Respondents are encouraged to choose the toys that have a harmless form such as pointed end to avoid the accidents that may occur while playing. The last priority was the type of toys. According to the Decree of Minister of Industry of the Republic of 
Indonesia No. 24/M-IND/PER/4/2013, the types of toys cover baby walker, wheeled toys, dolls, trains electric, assembly toy, toy construction, stuffed toy, various types of puzzles, blocks or pieces (figures, letters, animals, etc.), jump rope, marbles, balloons, and toy gun.

\section{Parents' Perception on Toys}

In general, more than half of respondents $(78.0 \%)$ had a good perception of toys that they had bought (Table 1). Thus, respondents perceived that purchased toys showing a satisfied performance were able to show a positive emotional value, and had a quality that was suitable with the price paid.

Table 1 Distribution of respondents based on perception level

\begin{tabular}{lc}
\hline Perception level & $\%$ \\
\hline Poor $($ score $\leq 66.6)$ & 22.0 \\
Good $($ score $\geq 66.7)$ & 78.0 \\
\hline Total & 100.0 \\
Mean \pm SD & $73.5 \pm 13.8$ \\
Minimum-maximum & $0.0-100.0$ \\
\hline
\end{tabular}

Table 2 shows that each dimension of perception had an average score that did not differ much. This indicates that there was no significant difference on each dimension of respondents' perception of toys. Generally, respondents scored the most excellent perception of the quality of toys in which the product had met or even exceeded the expectations of respondents. Respondents stated that children's products that had been purchased were made of good, safe, high quality, environmentally friendly materials, and they could function properly. Meanwhile, the most dominant emotional value perceived by the respondents was the guarantee of safety and comfort for children. The price was also perceived good in which respondents agreed that the price of purchased toys had met the quality and benefits received.

Table 2 Average percentage score of perceptions of toys

\begin{tabular}{lc}
\hline Perception dimension & Mean \\
\hline Quality of product & 75.0 \\
Emotional value & 71.3 \\
Suitablity price & 71.0 \\
\hline
\end{tabular}

\section{Parents' Involvement on Purcasing Decision of Toys}

Table 3 shows that nearly all respondents $(83.5 \%)$ showed low involvement on purchase decision of toys. It shows that respondents considered purchasing decisions as something that was not significantly risky.

Table 3 Distribution of respondents based on involvement level

\begin{tabular}{lc}
\hline Involvement level & $\%(\mathrm{n}=200)$ \\
\hline Low $($ score $\leq 66.6)$ & 83.5 \\
High $($ score $\geq 66.7)$ & 15.5 \\
\hline Total & 100.0 \\
Mean \pm SD & $56.7 \pm 12.5$ \\
Minimum-maximum & $0.0-100.0$ \\
\hline
\end{tabular}


Respondents indicated a long-term involvement of the highest compared to other involvement dimensions although it did not show large differences across these dimensions. Respondents decided to purchase toys for long term use and not only for the current purchase. They were not buying toys to earn praise from others on the evidence of concern for their children, but it was more because of other normative factors, one of which was to support the development of the child. Situational involvement of respondents dominantly were considering the appearance of toys before purchasing, but purchasing itself did not follow the trend or because of the discount. Meanwhile, respondents also considered the security risks for toys, but not because of the influence of advertising.

Table 4 Average score percentage of involvement on purchasing decision of toys

\begin{tabular}{lc}
\hline Involvement dimension & Mean \\
\hline Normative involvement & 56.9 \\
Subjective risk involvement & 59.7 \\
Long-term involvement & 60.2 \\
Situational involvement & 50.8 \\
\hline
\end{tabular}

\section{Purchasing Decision of Toys}

More than half of the respondents tended to buy toys on the child's birthday $(64.0 \%)$ and when the child asked $(59.0 \%)$. The main reason respondents made a purchase of toys was to enhance their child's development and fulfill their child's wishes. Half of the respondents $(51.0 \%)$ bought toys as many as 5 times or more per year with the same kinds of toys, namely one kind (47.5\%) and 2 kinds of toys $(34.5 \%)$.

Respondents' expense on toys varied with the highest proportion $(33.0 \%)$ was over Rp50.000 in one-time purchase. Location of toys purchases was determined by the allocation of time, cost, and availability of the desired product. Stores or toys wholesale (58.5\%) and shopping centers (malls, traditional markets/supermarkets) $(70.0 \%)$ became the prefered location more than online stores and toy peddlers. This was presumably because both locations had a variety of toys.

\section{Relationship between Respondent Characteristics and Purchasing Decisions of Toys (Purchase Frequency)}

The results showed that the husbands' length of education positively associated with frequency of purchase $(r=0.197, \mathrm{p}<0.01)$. The longer the husband pursued formal education, the higher the purchase frequency of toys. Likewise the length of education, the age of child also associated with frequency of purchase $(r=0.216, p<0.01)$. Respondents tended to increase their purchase frequency of toys along with the age of their child.

\section{Relationship between Perception, Involvement, and Purchasing Decision of Toys}

The results showed that the perception on toys positively associated with the involvement in purchasing decision $(\mathrm{r}=0.636, \mathrm{p}<0.01)$. The better the perception on toys, the higher the involvement in deciding the purchase. Perception was also proven to be positively associated with purchase frequency of toys $(\mathrm{r}=0.123, \mathrm{p}<0.01)$. This indicates that the better perception on toys, the higher the purchase frequency. 


\section{Factors That Influence Purchasing Decision of Toys}

Characteristics of respondents tested in the regression model consisted of: wife's length of education, husband's length of education, family income, age of the child, birth order of the child, and family size. Furthermore, frequency of purchases in one year was a key indicator of purchasing decisions resulting other indicators of purchasing decisions excluded in this regression model. Table 5 shows that the factors influencing significantly purchasing decisions of toys in terms of frequency of purchase was the age of the child $(B=0.246 ; p=0.012)$ and perceptions of toys $(B=0.183 ; p=0.044)$, that is, an increase in one-year age of the child would increase the frequency of purchase of toys by 0.246 times. Meanwhile, an increase of one unit of the respondent's perception score would increase the frequency of toy purchase by 0.183 times. This regression model explained the influence of these factors amounted to 5.4 percent on purchasing frequency while the rest was influenced by factors excluded in the study.

Table 5 Factors that influence the perception and involvement on purchasing decisions of toys (frequency of purchase within one year)

\begin{tabular}{|c|c|c|}
\hline \multirow[t]{2}{*}{ Variable } & \multicolumn{2}{|c|}{$\begin{array}{l}\text { Purchasing decision of toys } \\
\text { (frequency of purchase) }\end{array}$} \\
\hline & B & Sig. \\
\hline \multicolumn{3}{|l|}{ Constant } \\
\hline Wife's length of education (year) & -0.011 & 0.757 \\
\hline Husband's length of education (year) & -0.014 & 0.162 \\
\hline Family size (person) & 0.005 & 0.919 \\
\hline Family income (million/month) & 0.037 & 0.785 \\
\hline Age of the child (year) & 0.246 & $0.012 *$ \\
\hline Birth order of the child & 0.094 & 0.246 \\
\hline Perception & 0.183 & $0.044 *$ \\
\hline Involvement & 0.007 & 0.720 \\
\hline $\mathrm{F}$ & \multicolumn{2}{|c|}{2.256} \\
\hline Adjusted $\mathrm{R}^{2}$ & \multicolumn{2}{|c|}{0.054} \\
\hline Sig & \multicolumn{2}{|c|}{0.020} \\
\hline
\end{tabular}

Note. $\left.{ }^{*}\right)$ significant at $\mathrm{p}$-value $<0.05$

\section{Discussion}

Generally, this study aimed to assess the influence of the perception and the involvement of parents on purchasing decisions of toys. Respondents in this study were parents, mother or father as decision makers in the purchase of toys. Toys are the kinds of goods closely linked to children's health. Thousands of accidents happen to children because of toys. Most children misuse the toys because they do not know how to use them or the toys are not safe for children. Accidents caused by toys can be prevented by increasing the awareness of security products (Bapuji, Beamish, and Laplume, 2007). Safe goods are goods that protect the health and safety of consumers, both in terms of shape and size.

The cases found in the field become the basis of government to impose mandatory five SNI (Indonesian National Standard) toys contained in the Decree of Minister of Industry of the Republic of Indonesia No. 24/M-Ind/PER/4/2013. This 
regulation aims to provide security protection and safety for children. The government requires businesses and distributors to implement SNI toys and to make sure that the product meets the requirements of SNI. Efforts made by the government certainly needs the help parents as primary caregivers and providers of child development facilities including toys. Parents are expected to ensure the safety of toys for children by checking the size, shape and material of the toy, as well as providing appropriate toys to child development. Kids can give a quite big influence on purchasing decision of the family, except on the decision of how much money will be spent (Prasetijo and Ihalauw, 2005) so that parents also need to consider the child's wishes carefully.

Majority decision maker in the purchase of food products is a woman or a mother. This is in line with the study of Levy and Lee (2004), which showed that women tended to be a pioneer in making decisions. Besides gender, age can also influence consumer purchasing decisions. Sumarwan (2004) stated that the difference in consumption of products and services is affected by different consumer age. Age can affect how people think, feel, and behave in their purchasing decisions (Hawkins, Best, and Coney, 2001). The age of most of respondents in this study belonged to young adulthood (age 20-40 years) and the length of formal education of husband and wife was 10-12 years and over 12 years, respectively. Education can determine the income and position of a person (Hawkins, Best, and Coney, 2001). In general, wives did not have jobs or as housewives and husbands as private employees with family income ranged Rp5.000.000 - Rp2.500.001. Occupation can also impact the selection of products and consumption patterns (Kotler and Keller, 2009). Occupation is a single indicator to measure social class (Setiadi, 2010). Engel, Blackwell, and Miniard (1994) suggested that the consumers' income is one of the variables used to identify social status. More than half of respondents were a small family ( $\leq 4$ people). Family size would determine the amount and pattern of consumption of goods and services (Sumarwan, 2004). It does not merely influence purchasing behavior, but also affect how the allocation of household income for each family member. Child gender ratio in this study was similar to the range of 5 years old and was the eldest child or the only child.

The processing of information occurs when one of individual's senses receives input as a stimulus (Sumarwan, 2004). The ability of an individual to select, organize, and interpret the received stimuli is exactly what is called perception (Schiffman and Kanuk, 1983). Everyone has a tendency to see the same thing in different ways. Such differences may be influenced by many factors, including knowledge, experience, and perspective. Perception is also interlocked with the eyes of a person on a particular object in different ways by using sensing, then attempt to interpret it.

Respondents' perception of toys in this study was included in good category. Good perceptions refer to the consumers' ability to interpret information well. This is presumably because the respondents' knowledge about toys is very good. A good perception on toys is shown by the majority of respondents expressing agreement that the toys were consisted of good, safe, environmentally friendly materials and they worked well. Zeithaml (1988) identified the perceived quality of the product as a component of brand value in which high product quality perception will direct the 
consumer to choose the brand compared with competing brands. However, some respondents disagreed that the quality of toys were consistent from year to year. Most of respondents agreed evenly on the perception of the quality of the product, the emotional value of the product, and the suitability of the product price. Respondents give a different perception caused by an assessment that each individual against the same object will vary (Setiadi, 2010). Assael, as cited in Sutisna (2003), stated that the perception of a product was associated with the components (packaging, product parts, and shape) as well as communication shown to influence consumer behavior that reflects the product through the background of words, pictures, and symbolization or through other stimuli associated with the product (price, place, and sales).

The involvement of the respondents on purchasing decision of toys was included in the low category. This was demonstrated through disagreement almost half of the respondents on their involvement in the risk of subjective (113 respondents did not buy toys because of advertisements) and situational involvement (98 respondents did not buy toys because the product was being 'trend', 106 respondents did not buy toys because of discount, 120 respondents did not buy toys because of well-known toys). Respondents believed that it was unnecessary to involve a worrisome sense for false purchase and disloyal to the brand product at a particular time. However, it can cause accidents in children as a result of toys purchased by their parents. It is also seen on the priorities of respondents before buying toys. The 5th place priority of respondents was materials of toys; the 8th was size of toys; and the 9th priority was the form of toys. Thus, these three things have not been a major consideration in the decision to purchase toys; in fact it plays an important role in ensuring the children's safety. Mitigation of risks and hazards posed by the toys is done by identifying the specifications of toys (nature of the material, size, shape) and other types of warning signs on toys to be suited to the child's age. In addition, the safety standards of toys is also one of the key factors to recognize the character of the toy. Standards ensure the safety of toy when played (BSN, 2011).

More than half of respondents purchased toys at the time of the child's birthday (64.0\%) and when the child asks to buy (59.0\%). Nearly all respondents made a toys purchase with the aim of improving child development and fulfilling their child wishes. Almost all respondents purchased toys as many as five times or more within one year and bought one type of toys in one time purchase. Purchase locations chosen by nearly half of respondents were stores or wholesalers that specifically sold toys and shopping places, such as malls, supermarkets and traditional markets. One third of respondents (33.0\%) allocated above 50,000 for buying toys in one time purchase. Indonesia spending toys per capita reached an average of 120.000 per child per year (BSN, 2011) that it is still considered low compared with other countries, such as Singapore (Rp2 million per child) and China with similar profiles to Indonesia (Rp500.000).

In the process of marketing, perception is able to influence consumer behavior. In this study, the perception of respondents had a positive relationship with the length of education because it is related to information received by the individual. Thus, the education level enables individuals to be able to take into account the types of more 
profitable option. Study by Mityoko (2012) shows that an education plays a role in the consumer's perception towards a product.

Consumer's income is one of the variables that determine the economic status because it determines the amount of purchasing power. The economic status of consumers can also identify the selection of products to be bought (Kotler and Armstrong, 2008). The results showed that the perception and involvement had a positive relationship with the family income. This is important because the consumer's income will determine the amount of product that can be bought (Sumarwan, 2004). Individual's perceptions to an object may be different so that it will be subjective. Perception was affected by the thoughts and the surrounding environment. The increasing involvement will more motivate the individual to pay attention, understand, and elaborate the information (Mowen and Minor, 1998). Sutisna (2003) suggested that high levels of consumer involvement will lead more consumers look for and select information and become more cautious in making decisions. This is in line with the results of the correlation analysis in the study suggesting that the perception was closely associated to involvement. That is, the better perception, the higher involvement in deciding the purchase of toys.

Perception is positively correlated to frequency of purchase. These result is consistent with the study of Parasuraman, Zeithaml, and Berry (1985) which argued that there is a direct correlation between the perceived quality of the product with the frequency of purchase. In this study, the frequency of purchase becomes the indicator of toys purchase decisions as suggested by Kotler (2000). The result showed that the frequency of toy purchase was classified often or as many as 5 times or more to within one year.

Factors that significantly influenced purchasing decisions of toys in terms of frequency were the age of the child $(B=0.246 ; \mathrm{p}=0.012)$ and respondent's perceptions of toys $(B=0.183 ; p=0.044)$. This suggests that parents tended to increase the purchase frequency along with the age of the children.The same thing is applied to the high perception which would increase the purchase frequency of toys. These results are consistent with the study of $\mathrm{Li}$ and Lee (2001) in which a high perception will attract customers to buy or reuse services from the same provider. Conversely, if a product is perceived to have a poor quality, it will affect the brand image of the product. The higher the perception perceived by consumers, the higher the consumer's willingness to finally buy (Chapman and Wahlers, 1999).

\section{Conclusion and Recommendation}

\section{Conclusion}

This study aimed to assess the parents' perception and involvement that influence purchasing decisions of toys. Most of the respondents were female aged between 20-40 years (young adults). Nearly half of the respondents had a family income per month between Rp2.500.001 - Rp5.000.000 and the respondents' families were classified as a small family ( $\leq 4$ people). More than half of the husbands enrolled formal education for more than 12 years (higher education). Husbands worked as private 
employees while wives as housewives. Nearly half of the children aged 5 years old and were the eldest son or the first child. Generally, respondents had a good perception on toys. Thus, it affected the higher purchase frequency of toys. However, the low parent's involvement did not resulted in the same level of purchase frequency. In addition, the results proved that parents tended to increase the purchase frequency along with the age of the children.

\section{Recommendation}

Based on the results, the aspects of security, safety, and health of toys must fully be understood to provide protection for children. Parents are expected to be more prudent and selective in choosing and maintaining a safe, standardized, and appropriate toys, so as to minimize the hazards of toys for children. It is also a consideration for toys industry, especially in Indonesia to provide material products that are safe and healthy by including the full information (product labeling, product warning signs, and how to use the product) on the toy product package. Government is expected to increase its involvement in educating consumers about the purchasing decisions of toys. Government is also obliged to disseminate technical policies related to producers in order to create and strengthen cooperation in managing and developing industry that is able to produce qualified products. It is expected not only for the competence in the global market but also for the prevention of harm for consumers, children. Further research is suggested to complete the limited scope of the analysis in this research. The studies can be aimed at online gaming that is increasingly used by children but potentially pose a risk and danger for their physic, psychologic, mental, and brain. Research expansion is also necessary in terms of methods and aspects of observations to the things that are not analyzed in this study.

\section{Reference}

Bapuji, H., Beamish, P. W., \& Laplume, A. (2007). Toy import and recall levels: Is there a connection?. Research Reports, November. Asia Pacific Foundation Canada. Retrieved from https://www.asiapacific.ca/sites/default/files/filefield/Toy_recalls_0.pdf.

Chapman, J., \& Wahlers, R. (1999). A revision and empirical test of the extended priceperceived quality model. Journal of Marketing, 7(3), 53-64. doi: 10.1080/10696679.1999.11501840.

Engel, J. F., Blackwell, R. D., \& Miniard, P. W. (1994). Perilaku Konsumen [Consumer Behavior] (Vol. 1). (Budiyanto, Trans.). Jakarta, Indonesia: Binarupa Aksara.

Fauzi, M. (2011). Pengaruh persepsi konsumen terhadap pengambilan keputusan pembelian produk hand body lotion Vaseline for Men di Kelurahan Gaharu [Influence of consumers' perception on product purchase decision hand body lotion Vaseline For Men in gaharu Village] (Undergraduate thesis). Retrieved from http://repository.usu.ac.id/bitstream/123456789/26756/7/Cover.pdf. 
Guthrie, M. F., \& Hye-Shin, K. (2009). The relationship between consumer involvement and brand perceptions of female cosmetic consumers. Journal of Brand Management, 17(2), 114-133. doi: 10.1057/bm.2008.28.

Hawkins, D. I., Best, R. J., \& Coney, K. A. (2001). Consumer Behavior: Building Market Strategy (8th ed.). Boston, MA: Irwin/McGraw-Hill Co.

Herjanto, E., \& Rahmi, D. (2010). Kajian pemberlakuan secara wajib standar mainan anak-anak [Study on the mandatory standards of children's toys]. Jurnal Riset Industri, $\quad 4(1), \quad 1-16 . \quad$ Retrieved from http://ejournal.kemenperin.go.id/jri/article/view/63/59

Kotler, P. (2000). Manajemen Pemasaran [Marketing Management]. (Milenium ed.). Jakarta, Indonesia: PT. Indeks Kelompok Gramedia.

Kotler, P., \& Armstrong, G. M. (2008). Principles of Marketing. New Jersey, NJ: Pearson/Prentice Hall.

Kotler, P., \& Keller, K. L. (2009). Manajemen Pemasaran [Management Marketing] (13th ed.). Jakarta, Indonesia: Penerbit Erlangga.

Levy, D. S., \& Lee, C. K. C. (2004). The influence of family members on housing purchase decision. Journal of Property Investment \& Finance, 22(4), 320-338. doi: $10.1108 / 14635780410550885$.

Li, C, \& Lee, J. (2001). Dimensions of service and their influence on intention to repurchase. In S. Williamson \& H. Lemelin (eds.), Proceedings of the 9th Leisure Research Symposium: A Leisure Odyssey; May 3-4, 2001. University of Waterloo, Waterloo, Canada. 13-17.

Mityoko, D. S. V. (2012). Consumers' education level impact on the perception of the search experience credence products - empirical evidence. Journal of Internet and e-Business Studies, 1-8. doi: 10.5171/2012.617588.

National Population and Family Planning Board. (2005). Profil Hasil Pendataan Keluarga [Profile of Family Data Collection Results]. Jakarta, Indonesia: Author.

National Standardization Agency of Indonesia. (2011). Kompendium Keamanan Mainan Anak [Toy Safety Compendium]. Jakarta, Indonesia: Author.

Parasuraman, A., Zeithaml, V. A., \& Berry, L. L. (1985). A conceptual model of service quality and its implications for future research. Journal of Marketing. 49, 41-50. Retrieved from http://areas.kenanflagler.unc.edu/Marketing/FacultyStaff/zeithaml/Selected\%20Publications/A\%20Co nceptual\%20Model\%20of\%20Service\%20Quality\%20and\%20Its\%20Implications\% 20for\%20Future\%20Research.pdf.

Prasetijo, R., \& Ihalauw, J. J. O. I. (2005). Perilaku Konsumen [Consumer Behavior]. Yogyakarta, Indonesia: Penerbit Andi.

Setiadi, N. J. (2010). Perilaku Konsumen: Konsep dan Implikasi untuk Strategi dan Penelitian Pemasaran ([Consumer Behavior: Concepts and Implications for Strategy and Marketing Research]. Jakarta, Indonesia: Kencana Prenada Media.

Sumarwan, U. (2004). Perilaku Konsumen: Teori dan Penerapannya dalam Pemasaran [Consumer Behavior: Theory and Application in Marketing]. Bogor, Indonesia: PT Ghalia Indonesia. 
Sutisna. (2003). Perilaku Konsumen dan Komunikasi Pemasaran [Consumer Behavior and Marketing Communications] (3rd ed.). Bandung, Indonesia: PT. Remaja Rosdakarya.

Wijayanti, M. (2009). Pengaruh keterlibatan konsumen terhadap kepercayaan merek dan dampaknya terhadap keputusan pembelian [Influence of consumer involvement on brand trust and its impact on purchasing decisions] (Undergraduate thesis). Retrieved from http://e-journal.uajy.ac.id/3439/.

Zeithaml, V. A. (1988). Consumer perceptions of price, quality, and value: A meansend model and synthesis of evidence. Journal of Marketing, 52, 52-54. doi: $10.2307 / 1251446$. 